DOI 10.4467/12332135KRA.21.010.14689

\title{
Popularyzacja zasobu i działalności Archiwum Narodowego w Krakowie w 2021 r.
}

Działalność popularyzatorska w 2021 r., podobnie jak w 2020 r., różniła się od dotychczasowej ze względu na pandemię SARS-CoV-2. Epidemia koronawirusa i trwająca przeprowadzka zasobu do nowej siedziby znacząco wpłynęły na organizację pracy Archiwum w każdym obszarze jego działalności. Utrudniony dostęp do materiałów archiwalnych, zamknięcie czytelni, ograniczenia spotkań związane z reżimem sanitarnym, nauka zdalna w szkołach i uczelniach - wszystko to przyczyniło się do uszczuplenia planowanej liczby wydarzeń na polu popularyzacji i edukacji. Pomimo niesprzyjających okoliczności w 2021 r. realizowano wiele zadań z tego zakresu online, a w drugiej jego połowie również stacjonarnie.

Oddanie w 2020 r. do użytku nowoczesnej siedziby przy ul. Rakowickiej 22E wyznaczyło nowy rozdział w historii naszej instytucji. W obliczu tego przełomowego wydarzenia naturalnie zrodziła się potrzeba podsumowania dotychczasowej ponad 140-letniej działalności. Wielkim wyróżnieniem był dla nas fakt, że bogata historia krakowskiego Archiwum związana z gromadzeniem i zabezpieczaniem akt miejskich została upamiętniona jednomyślną uchwałą Rady Miasta Krakowa z dnia 26 maja 2021 r. (NR LVIII/1709/21), na mocy której plac u zbiegu ul. św. Krzyża i ul. Siennej nosi dziś miano „Plac Archiwum Aktów Dawnych Miasta Krakowa". Obszar placu położony jest w pobliżu historycznej siedziby Archiwum przy ul. Siennej 16, do niedawna również główniej siedziby ANK. Archiwum Aktów Dawnych Miasta Krakowa, działające w latach 1887-1952, było instytucją miejską, która - wraz z Krajowym Archiwum Aktów Grodzkich i Ziemskich w Krakowie - stworzyła podwaliny obecnie funkcjonującego Archiwum Narodowego w Krakowie. 15 lipca 2021 r. odbyła się uroczystość nadania nazwy placowi i odsłonięcia tabliczki z udziałem: Zastępcy Prezydenta Krakowa ds. Zrównoważonego Rozwoju Miasta Jerzego Muzyka, Sławomira Pietrzyka, wiceprzewodniczącego Rady Miasta Krakowa, dr. hab. Wojciecha Krawczuka, prof. UJ, dyrektora Archiwum Narodowego w Krakowie oraz dr Kamili Follprecht, zastępcy dyrektora Archiwum Narodowego w Krakowie. Prezydent J. Muzyk, który w imieniu Prezydenta Miasta Krakowa prof. Jacka Majchrowskiego reprezentował Magistrat krakowski, podkreślił w swoim wystąpieniu znaczenie dla tożsamości mieszkańców miasta bogatego zasobu ANK, spadkobiercy Archiwum Aktów Dawnych Miasta Krakowa. Podziękował też pracownikom Archiwum za aktywność, prace badawcze i wartości, tak istotne dla utrwalania historii miasta. Dr K. Follprecht przybliżyła dzieje i znaczenie Archiwum Aktów Dawnych Miasta Krakowa, zaznaczając, że budynek Archiwum był też kolebką przyszłego Muzeum Historycznego Miasta Krakowa oraz założonego przez grupę pasjonatów Towarzystwa Miłośników Historii i Zabytków Krakowa. Uroczystość, zorgani- 
zowaną przez Urząd Miasta Krakowa oraz Archiwum Narodowe w Krakowie, zakończono złożeniem podpisów upamiętniających to wydarzenie w księdze pamiątkowej Archiwum. Bogato zdobiona księga z 1915 r. stanowi dar znanego krakowskiego introligatora Roberta Jahody dla Archiwum Aktów Dawnych Miasta Krakowa. Nadanie nazwy placowi leżącemu naprzeciwko kamienicy, w której od 1887 r. przechowywane są krakowskie archiwalia, stanowi tym większe wyróżnienie, że nieczęsto ulice i place noszą nazwy pochodzące od instytucji archiwalnych. W ten sposób Kraków złożył hołd placówce, która dla przyszłych pokoleń przechowała dokumenty świadczące o historii miasta od średniowiecza do czasów współczesnych.

Kolejnym wydarzeniem, które dzięki spadkowi liczby zachorowań mogło się odbyć stacjonarnie, były cykliczne obchody Europejskich Dni Dziedzictwa - uczestniczył w nich bocheński oddział ANK, zapraszając do swojej siedziby w willi „Pod Kozłem” (projektu Teodora Talowskiego) zainteresowanych zabytkami powiatu Bocheńskiego. Oddział w Bochni (Agnieszka Gicala i Dorota Szymczyk) włączył się również w jubileuszowe obchody organizowane przez miasto Niepołomice w 100. rocznicę objęcia stanowiska pierwszego burmistrza w wolnej Polsce przez Andrzeja Wimmera.

Archiwum, w dniach 16-17 września 2021 r., było też współorganizatorem konferencji „Archiwa ponadnarodowe. Wspólne dziedzictwo - różne rozwiązania”. Uniwersytet Pedagogiczny im. KEN w Krakowie, pomysłodawca projektu, przygotował obrady w formule hybrydowej, stacjonarnie odbywały się w Krzysztoforach (Muzeum Krakowa). W konferencji uczestniczyli goście z zagranicy i z Polski, w tym przedstawiciele archiwów organizacji międzynarodowych. Z ramienia sieci archiwów państwowych na konferencji wystąpiły: dr hab. Lucyna Harc, zastępca Naczelnego Dyrektora Archiwów Państwowych, która otworzyła konferencję, dr K. Follprecht, która przywitała gości w imieniu współorganizatora (ANK); dr Anna Laszuk (NDAP) wygłosiła referat o działalności humanitarnej i zbiorach dokumentacji Międzynarodowej Służby Poszukiwań w Bad Arolsen oraz Iwona Fischer (ANK) przybliżyła w swoim wystąpieniu przechowywane w zasobie Archiwum Narodowego w Krakowie zbiory ukrainików. Konferencję patronatem honorowym objęli: Minister Spraw Zagranicznych prof. Zbigniew Rau oraz Naczelny Dyrektor Archiwów Państwowych dr Paweł Pietrzyk. Uczestnicy konferencji zwiedzili również wystawę towarzyszącą wydarzeniu „Rząd na emigracji, kancelaria poza krajem...” (kurator I. Fischer) oraz nową siedzibę Archiwum przy ul. Rakowickiej 22E.

30 września już po raz trzeci Archiwa Państwowe świętowały Dzień Archiwisty, z tej okazji przygotowano dla wielbicieli fotografii wystawę plenerową „Za obiektywem. Krakowskie zakłady fotograficzne pierwszej połowy XX wieku” (kurator dr Barbara Zbroja), dostępną dla zwiedzających w dniach 30 września - 6 listopada 2021 r. przed nową siedzibą Archiwum. Partnerem projektu było Muzeum Fotografii w Krakowie. Obchody Dnia Archiwisty w Archiwum Narodowym w Krakowie Oddział w Nowym Sączu zbiegły się z wydarzeniami związanymi z Rokiem Barbackiego, tj. podwójnym jubileuszem 130-lecia urodzin i 80. rocznicy śmierci artysty. Bolesław Barbacki był wybitnym polskim portrecistą, pedagogiem i społecznikiem, związanym całe życie z miastem Nowym Sączem. Pracownicy nowosądeckiego Oddziału ANK (Agnieszka Filipek i Agnieszka Jeleń) przygotowali dla uczniów i nauczycieli m.in. kilka tur pokazów materiałów archiwalnych związanych z tą postacią. Także w siedzibie Oddziału uczestnicy gry miejskiej „Na tropie 
Bolesława Barbackiego" mieli wykonać kulminacyjne zadanie rozgrywki. Organizatorami gry byli: Sądecka Biblioteka Publiczna im. Józefa Szujskiego, Fundacja EUROS - WIATR ZE WSCHODU oraz krakowski Oddział Instytutu Pamięci Narodowej.

Ponieważ sytuacja epidemiczna wymusiła na Archiwum częściowe zamknięcie instytucji dla odbiorców i gości, swoją pracę przenieśliśmy do sieci i staraliśmy się wypełnić kulturą przestrzeń online. Docieraliśmy do odbiorców poprzez stronę internetową, portale tematyczne „Dawne Pismo” oraz „Archiwalne opowieści”, a także przez social media.

W ramach cyklów popularyzatorskich: „Luminarze”, „Budowali Kraków” oraz „Porozmawiajmy o źródle archiwalnym" prezentowano wystawy internetowe i filmowe pokazy materiałów archiwalnych przygotowane przez: dr K. Follprecht, Konrada Myślika, Liliannę Pochwalską, dr. hab. Marcina Starzyńskiego, prof. UJ, dr B. Zbroję. Z myślą o publiczności, która odwiedzi nas przez Internet, przygotowano również w ramach ogólnopolskich obchodów rocznicowych wystawę „Vivat Konstytucja 3 Maja. 230. rocznica uchwalenia pierwszej w Europie nowoczesnej konstytucji” (dr Barbara Berska), a także w ramach Międzynarodowego Dnia Archiwów prezentację „Pamięć Świata. Pamięć Narodu. Program »Pamięć Świata« UNESCO i udział w nim Archiwum Narodowego w Krakowie” (B. Berska, Tomasz Wroński).

Archiwum kontynuowało również projekty realizowane przez sieć archiwów państwowych, jak: „Archiwum Pandemii. Społeczna kolekcja dokumentów pandemii wywołanej koronawirusem (SARS-CoV-2)” czy „Archiwa Rodzinne Niepodległej”. Pokłosiem realizacji tego ostatniego jest przygotowanie do druku w 2021 r. publikacji Eugeniusz Jelonek - Wspomnienia o pociagu pancernym „Smok” (1919) (wyd. Krystyna Jelonek-Litewka i Aleksander Litewka przy współpracy T. Wrońskiego).

Lilianna Pochwalska Archiwum Narodowe w Krakowie 